\title{
ESTIMATING THE EFFECTS OF MILK INSPECTIONS \\ ON INFANT AND CHILD MORTALITY, 1880-1910
}

\author{
D. Mark Anderson \\ Kerwin Kofi Charles \\ Michael McKelligott \\ Daniel I. Rees \\ Working Paper 29620 \\ http://www.nber.org/papers/w29620 \\ NATIONAL BUREAU OF ECONOMIC RESEARCH \\ 1050 Massachusetts Avenue \\ Cambridge, MA 02138 \\ December 2021
}

Partial support for this research came from a Eunice Kennedy Shriver National Institute of Child Health and Human Development research infrastructure grant, R24 HD042828, to the Center for Studies in Demography and Ecology at the University of Washington. Support also came from the Comunidad de Madrid, grant EPUC3M11 (V PRICIT) and grant H2019/HUM-5891. The views expressed herein are those of the authors and do not necessarily reflect the views of the National Bureau of Economic Research.

NBER working papers are circulated for discussion and comment purposes. They have not been peer-reviewed or been subject to the review by the NBER Board of Directors that accompanies official NBER publications.

(C) 2021 by D. Mark Anderson, Kerwin Kofi Charles, Michael McKelligott, and Daniel I. Rees. All rights reserved. Short sections of text, not to exceed two paragraphs, may be quoted without explicit permission provided that full credit, including $\odot$ notice, is given to the source. 
Estimating the Effects of Milk Inspections on Infant and Child Mortality, 1880-1910

D. Mark Anderson, Kerwin Kofi Charles, Michael McKelligott, and Daniel I. Rees

NBER Working Paper No. 29620

December 2021

JEL No. I18,J1,N31

\section{ABSTRACT}

In the mid-19th century, the urban milk supply in the United States was regularly skimmed or diluted with water, reducing its nutritional value. At the urging of public health experts, cities across the country hired milk inspectors, who were tasked with collecting and analyzing milk samples with the goal of preventing adulteration and skimming. Using city-level data for the period 1880-1910, we explore the effects of milk inspections on infant mortality and mortality among children under the age of 5. Event-study estimates are small and statistically insignificant, providing little evidence of post-treatment reductions in either infant or child mortality.

D. Mark Anderson

Department of Agricultural Economics

\& Economics

Montana State University

P.O. Box 172920

Bozeman, MT 59717

and NBER

dwight.anderson@montana.edu

Kerwin Kofi Charles

School of Management

Yale University

165 Whitney Avenue

New Haven, CT. 06511

and NBER

kerwin.charles@yale.edu
Michael McKelligott

Harris School of Public Policy

University of Chicago

1307 E 60th St

Chicago, IL 60637

mckelligott@uchicago.edu

Daniel I. Rees

Department of Economics

Universidad Carlos III de Madrid

Calle Madrid 126

28903 Getafe

Spain

Daniel.Rees@uc3m.es 


\section{Introduction}

Nineteenth century cities were filthy and rife with disease. Nonetheless, urban mortality rates in the United States began to fall in the 1870s and continued to fall through the first several decades of the $20^{\text {th }}$ century (Higgs 1979; Haines 2001). By the 1940s, the urban mortality penalty had been eliminated (Haines 2001). This phenomenon, referred to as the mortality transition, was driven primarily by reductions in infant mortality and infectious diseases (Costa 2015).

What factors drove the mortality transition? This has been called "the most important question in medical history" (McKeown and Brown 1955, p. 139), but the causes of the mortality transition are still poorly understood. McKeown (1976) and Fogel (1997) point to the onset of modern economic growth and attendant improvements in nutrition, while recent reviews of the literature emphasize the role of public health, especially efforts to purify municipal water supplies (Cutler et al. 2006; Costa 2015).

The focus of the current study is on efforts to provide American city dwellers with clean milk, as opposed to clean water. In the mid- $19^{\text {th }}$ century, the urban milk supply was regularly skimmed or diluted with (potentially contaminated) water, reducing its nutritional value; caramel, salt, and sugar were added to restore its body, color, and taste; boric acid was often added as a preservative (Newton 1877; Martin 1884; Kastle 1908; Hart 1952). ${ }^{1}$ Public health experts began sounding the alarm in the 1870 s, claiming these practices were killing thousands of children every year (Meckel 1990, p. 68). In response, city governments hired milk inspectors, who were tasked

\footnotetext{
1 Today, boric acid is used as an insecticide and fungicide (See et al. 2010). Derived from borax, it is toxic and, if ingested by humans, can cause abdominal pain, diarrhea, and vomiting (Litovitz et al. 1988). There had been consumer complaints about adding borax to milk for decades ("Pure and Impure Milk" 1876, p.9; "Dangerous Milk Adulteration" 1879, p. 2; "How Milk is Adulterated” 1887, p. 10; “A Chemical Examination Shows Borax Acid in Milk" 1889, p. 1.) but the practice was still widespread at the turn of the $20^{\text {th }}$ century and vigorously defended by dairy interests (Committee on Interstate and Foreign Commerce 1902). Other preservatives frequently added to milk in the 19 th century include formaldehyde, sodium carbonate, and sodium bicarbonate (Newton 1877; Drescher 1893; Hart 1952).
} 
with collecting and analyzing milk samples from dairymen and dealers. ${ }^{2}$ If the milk was found to have been adulterated or skimmed, then stiff fines were levied and the milk was confiscated or spilled onto the ground.

There is anecdotal evidence that milk inspections were effective. For instance, 40 percent of the milk sold in New York City was either diluted with water or skimmed in 1882, the year before inspections began; the next year, only 20 percent of the New York City supply was watered or skimmed (Morris 1885). According to one contemporary observer, a Dr. H.A. Pooler, the milk inspections "had a very happy effect by reducing the death rate of children...3,673 less in 1883 than in 1882, other conditions of the city being about the same" (Morris 1885, p. 250).

Using city-level data for the period 1880-1910, we estimate the effects of milk inspections on infant and child deaths per 100,000 population. Mortality counts come from a variety of historical sources, including public health reports available in the archives of the National Library of Medicine and the U.S. Census Bureau's Mortality Statistics. During the 1880s and 1890s, most major cities in the United States undertook regular inspections of their milk supply with the goal of preventing its adulteration and skimming. When analyzing infant mortality, we are able to exploit pre- and posttreatment data from 30 American cities; when analyzing mortality among children under the age of 5, we exploit pre- and post-treatment data from 28 cities.

Our event-study estimates provide little evidence that milk inspections were effective. In the post-treatment period, estimated effects of milk inspections on infant and child mortality are

\footnotetext{
2 On-the-spot analysis of milk samples could be performed with a "lactometer," an instrument used to check milk density. Geisler (1891 p. 93) provided instructions for its use:

The milk to be tested should be warmed or cooled, as the case may be, to the temperature of $60^{\circ}$ Fahr. The lactometer is placed in it, care being taken not to wet that part of the stem above the milk. Now take the lactometer out of the milk and observe whether the thin film adhering to it runs rapidly off, and whether the milk appears thin and blueish and the taste of the milk is flat and watery: if such is the case and the lactometer floats at some point less than 100_as, for instance, 90 — then we are reasonably certain that water has been added.
} 
generally small and, without exception, statistically insignificant at conventional levels. We conclude that milk inspections may have reduced infant and child mortality, but their effects were not sufficiently large so as to be reliably detectable.

\section{Background}

Exclusive breastfeeding was not the norm at the turn of the $20^{\text {th }}$ century among American mothers. For example, Wolf $(2001,2003)$ reports that most mothers in Chicago did not exclusively

breastfeed their newborns and, as a consequence, diarrhea was the leading cause of infant mortality. ${ }^{3}$ Instead of breast milk, mothers typically fed their infants a gruel that contained water and cows' milk (Alsan and Goldin 2019).

Because infants were weaned at such an early age, the diluting of cows' milk with water represented a direct threat to their health. Although it was widely recognized that water could carry deadly pathogens such as diphtheria and typhoid, public health officials in the 1870s and 1880s were focused on ensuring that infants received adequate nutrition (Meckel 1990, pp. 68-70). ${ }^{4}$ Several cities had already prohibited the selling of adulterated food and milk, but these ordinances appear to have been of little practical value either because "adulteration" was vaguely defined or inadequate provision was made for enforcement. ${ }^{5}$ The hiring of milk inspectors was viewed as a crucial step

\footnotetext{
${ }^{3}$ In 1912, the Journal of the American Medical Association lamented that the "nursing period has gradually been diminished to one year, then to six months, then to three months, and now it is largely a question as to whether the mother will nurse her baby at all" ("The Care of Infants" 1912, p. 542).

${ }^{4}$ For instance, Newton (1877, p. 222), the New Jersey milk inspector, wrote:

If we try to nourish a child on skimmed or water milk, fat in insufficient quantities is supplied, wasting results, death may follow; or, in other words, the child is starved...Milk, being the principal article of diet in infancy, we naturally turn to that period of life to find the effects of impure milk; and it is just at that period of life that we note the highest mortality. Thousands of children perish annually from starvation due to feeding on skimmed and watered milk.

${ }^{5}$ In February of 1880, the Boston milk inspector complained that "under existing laws, it was almost impossible to convict the sellers of watered or doctored milk ("The Adulteration of Milk" 1880, p. 2). Shortly thereafter, a pure milk standard was adopted as were new penalties for selling adulterated or skimmed milk ("The New Milk Law" 1880, p. 1).
} 
towards reducing the alarmingly high rates of infant mortality. Perhaps because of data limitations, no previous study has investigated whether it was effective.

By the late 1800s, public health officials had shifted their focus from preventing the skimming and watering of milk to preventing its contamination with harmful microscopic pathogens (Meckel 1990, p. 70). These efforts included requirements that milk sold within city limits meet strict bacteriological standards (e.g., a maximum of 500,000 bacteria per cubic centimeter of milk), requirements that milk come from tuberculin-tested cows, dairy farm inspections, and the licensing of milk sellers (Parker 1917; Preston and Haines 1991; Anderson et al. 2022). ${ }^{6}$ Using data from 26 cities for the period 1900-1940 and a difference-in-differences (DD) regression, Anderson et al. (2022) found no evidence that infant mortality was related to either the adoption of bacteriological standards or the requirement that milk come from tuberculin-tested cows. Descriptive evidence from Lentzner (1987) suggests that the licensing of milk sellers was similarly ineffective.

Using data from 40 U.S. cities for the period 1900-1920 and a DD model, Komisarow (2017) investigated the effects of dairy farm inspections on mortality from diarrhea and enteritis among infants and young children. She found that dairy farm inspections were associated with a 1420 percent reduction in mortality from diarrhea and enteritis among one-year-olds. Although there was no evidence of an effect on infant mortality, Komisarow's inspection dates came from Parker (1917, Table 114, p. 371) and are, with some frequency, contradicted by information available from other contemporary sources (e.g., newspaper accounts and public health reports). Moreover, it is

\footnotetext{
In June of 1890, the Philadelphia milk inspector complained that in order to obtain a conviction, "the act of adulteration must be witnessed by an officer of the law." ("Long Live the Pump" 1890, p. 8). Later that year, a new ordinance defining what constituted impure milk was passed by the Philadelphia City Council ("Sale of Impure Milk" 1890, p. 3).

"Ordinances requiring milk to meet bacteriological standards are often referred as "pasteurization ordinances" (Troesken 2015, pp. 33-34; Komisarow 2017, p. 131) because these standards were difficult to meet without resorting to pasteurization (Meckel 1990, pp. 88-89).
} 
not clear whether the dates provided by Parker (1917) correspond to when dairy farms within city limits were first inspected or whether the inspections extended to farms located outside city limits.

\section{Data and Methods}

The mortality data used in the analysis are at the city level and were collected from a variety of sources. For the pre-1900 period, mortality counts come from municipal and state public health reports, obtained either through interlibrary loan, the Hathi Trust Digital Library, or the archives at the National Library of Medicine in Bethesda, Maryland. ${ }^{7}$ For the years 1900-1910, mortality counts come from Mortality Statistics, published annually by the U.S. Census Bureau.

Figure 1 shows trends in infant and child deaths per 100,000 population for the cities in our sample. From 1880 to 1910, the infant mortality rate fell from 601.6 to 318.5, or 47 percent. The decline in child mortality was even more dramatic, falling from 1,007.2 to 418.2 (58 percent). The most notable mortality reductions occurred in the 1890s, although chlorine was not added to drinking water until 1908 and water filtration plants were largely a post-1900 phenomenon (Anderson et al. 2020; Anderson et al. 2022). Figure 1 is, to our knowledge, the first attempt to document pre-1900 trends in infant and child mortality for such a broad sample of American cities. ${ }^{8}$

To investigate whether the trends shown in Figure 1 can be explained by milk inspections, we estimate a two-way fixed effects regression model:

\footnotetext{
${ }^{7}$ For example, mortality data for St. Louis, MO come from city health department reports and were obtained from the St. Louis Public Library via interlibrary loan (1880-1896) and the Hathi Trust Digital Library (1897-1899). To take another example, mortality data for Cleveland, $\mathrm{OH}$ were obtained from the Hathi Trust Digital Library (1880-1883, 1892, 1895, 1898-1899), the Cleveland Public Library via interlibrary loan (1884-1885), and the archives at the National Library of Medicine (1886-1891, 1893-1894, 1896-1897). See Appendix Table A1 for a list of the cities and years used in our analysis. We collected mortality data for several major U.S. cities that were ultimately excluded from our analysis. These cities were excluded either because we could not determine when milk inspections began or because they would have entered our sample as "always-treated" units (Goodman-Bacon 2021).

${ }^{8}$ Anderson et al. (2021a) showed infant mortality trends over the period 1880-1940 for 14 U.S. cities.
} 


$$
M R_{\mathrm{ct}}=a_{0}+v_{c}+\lambda_{t}+\sum_{y=-7}^{-2} \pi_{y} 1\left(t-T_{c}^{*}=y\right)+\sum_{y=0}^{7} \pi_{y} 1\left(t-T_{c}^{*}=y\right)+\boldsymbol{X}_{c t} \beta+\varepsilon_{c t,}
$$

where $M R_{c t}$ is the infant (or child) mortality rate in city $c$ and year $t=1880 \ldots 1910{ }^{9}$ City fixed effects, $v_{c}$, account for time-invariant determinants of mortality; year fixed effects, $\lambda$, account for common shocks. The event-year dummies, $y$, are equal to 1 when the year of observation is $y$ $=-7, \ldots, 0, \ldots 7$ years from $T_{c}^{*}$, the year in which city $c$ 's milk supply was first regularly sampled and inspected with the goal of preventing adulteration and skimming. Finally, the vector $\boldsymbol{X}_{c t}$ includes controls for whether city $c$ filtered its water, treated it with chlorine, or had undertaken a major clean water project. ${ }^{10}$ Appendix Table 2 provides descriptive statistics.

\section{Results}

We report ordinary least squares (OLS) estimates of equation (1) in Panel A of Figure 2. With or without controlling for other public health interventions, these estimates exhibit a similar pattern: there is little evidence of systematic pre-treatment trends, while the post-treatment estimates of $\pi_{y}$ are generally small and statistically insignificant at conventional levels. Based on the lower bounds of their 90 percent confidence intervals, we can easily reject the hypothesis that milk inspections drove the dramatic reductions in infant and child mortality shown in Figure $1 .^{11}$

\footnotetext{
${ }^{9}$ We omit $y=-1$ from equation (1), which normalizes the estimates of $\pi_{y}$ to 0 in that year. The $y=-7$ event-year dummy is equal to 1 if $t$ is 7 or more years before $T_{c}^{*}$. Likewise, the $y=7$ event-year dummy is equal to 1 if $t$ is 7 or more years after $T_{c}^{*}$. The results presented below are qualitatively similar if we define the event-year dummies based on alternative time horizons.

${ }^{10}$ Appendix B provides sources for the water-related intervention dates. See Anderson et al. (2021b, 2022) for more information on the water-related interventions included in $\boldsymbol{X}_{\boldsymbol{c t}}$. We also experimented with controlling for dairy farm inspections based on the dates provided in Parker (1917, Table 114, p. 371). Doing so did not materially change the estimates reported below.

${ }^{11}$ For instance, in event-year $y=2$ (and controlling for other public health efforts), milk inspections are associated with 9.93 fewer infant deaths per 100,000 population $(\mathrm{p}$-value $=0.389)$. The lower bound of the 90 percent confidence interval for this estimate is -29.2 , which represents a 5.3 percent reduction relative to the pre-treatment mean, or 10.3 percent of the actual reduction in the infant mortality rate over the period 1880-1910.
} 
If the effects of milk inspections on infant mortality were dynamic and heterogeneous, then our estimates of $\pi_{y}$ are potentially biased (Sun and Abraham 2021). In Panel B of Figure 2, we report results from the interaction-weighted estimator proposed by Sun and Abraham (2021), which uses never-treated or last-treated units as counterfactuals and is more robust to treatment effect heterogeneity. ${ }^{12}$ While less precise and often positive in the post-treatment period, the interactionweighted estimates exhibit a similar overall pattern to those shown in Panel A of Figure $2 .{ }^{13}$

In Panel A of Figure 3, we report estimates of equation (1), replacing infant deaths per 100,000 population with the child mortality rate. There is little evidence that child mortality fell after regular milk inspections were undertaken. The post-treatment estimates of $\pi_{y}$ are, without exception, statistically insignificant at conventional levels and exhibit no clear-cut pattern. Again, we can reject the hypothesis that milk inspections contributed meaningfully to the observed mortality reductions during the period under study (Figure 1). ${ }^{14}$ The interaction-weighted estimates, reported in Panel B, are often positive in the post-treatment period and are never statistically significant.

\section{Conclusion}

Recent descriptions of the mortality transition and its causes have focused on efforts to purify municipal water supplies (Cutler et al. 2006; Costa 2015), while other scholars have

\footnotetext{
12 The Sun and Abraham (2021) interaction-weighted estimator represents a special case of the estimator proposed by Callaway and Sant'Anna (2021). To implement the interaction-weighted estimator, we defined our counterfactual units as never-treated cities and cities that began inspecting their milk in 1900 or later, effectively limiting the analysis period to 1880-1899. Interaction-weighted estimates based on using either never-treated or late-treated cities as comparisons were qualitatively similar to those shown in Figure 2.

${ }^{13}$ We also experimented with controlling for underlying trends in a variety of ways (e.g., including city-specific trends, timing-group-specific trends, and state-by-year fixed effects). These experiments produced no consistent evidence that milk inspections were negatively related to infant mortality.

${ }^{14}$ For instance, in event-year $y=2$ (and controlling for other public health efforts), milk inspections are associated with 25.3 fewer child deaths per 100,000 population $(\mathrm{p}$-value $=0.223$ ). The lower bound of the 90 percent confidence interval for this estimate is -66.8 , which represents a 7.6 percent reduction relative to the pre-treatment mean, or 11.3 percent of the actual reduction in the child mortality rate over the period 1880-1910.
} 
emphasized the importance of clean milk, especially for infant and early child mortality (North 1921; Preston and Haines 1991; Lee 2007). Using city-level data for the period 1880-1910, we investigate the effects of municipal milk inspections on infant and child mortality. These inspections were undertaken at the urging of public health experts with the goal of preventing the adulteration and skimming of urban milk supplies.

Our post-treatment estimates are generally small and, without exception, statistically insignificant at conventional levels. This pattern of results is consistent with Preston and Haines's (1991) observation that public health efforts undertaken before the turn of the $20^{\text {th }}$ century did not materially improve the quality of urban milk supplies. It is possible that heating milk in the home, a practice introduced from Germany in the 1880s (Ewbank and Preston 1989), did more to protect infants and children from deadly pathogens commonly found in milk than did municipal inspections. Alternatively, new technologies, including the introduction of mechanical ice in the 1880s (Rees 2013), may have played an important role.

\section{References}

“A Chemical Examination Shows Borax Acid in Milk." 1889. The Wichita Star, July 27, p. 1.

Anderson, D. Mark, Kerwin Kofi Charles, and Daniel I. Rees. 2022. "Re-Examining the Contribution of Public Health Efforts to the Decline in Urban Mortality." American Economic Journal: Applied Economics, In Press.

Anderson, D. Mark, Kerwin Kofi Charles, and Daniel I. Rees. 2021a. "Public Health Efforts and the US Mortality Transition.” NBER Reporter, No. 3, October 7.

Anderson, D. Mark, Kerwin Kofi Charles, Daniel I. Rees, and Tianyi Wang. 2021b. "Water Purification Efforts and the Black-White Infant Mortality Gap, 1906-1938.” Journal of Urban Economics, 122(March): 103329.

Anderson, D. Mark, Daniel I Rees, and Tianyi Wang. 2020. “The Phenomenon of Summer Diarrhea and its Waning, 1910-1930." Explorations in Economic History, 78(October): 101341.

Alsan, Marcella and Claudia Goldin. 2019. "Watersheds in Child Mortality: The Role of Effective Water and Sewerage Infrastructure, 1880 to 1920.” Journal of Political Economy, 127(2): 586-638. 
Callaway, Brantly and Pedro H.C. Sant'Anna. 2021. "Difference-in-Differences with Multiple Time Periods." Journal of Econometrics, 225(2): 200-230.

Committee on Interstate and Foreign Commerce. 1902. "The Pure-Food Bills H.R. 3109, 12348, 9352, 276, and 4342 for Preventing the Adulteration, Misbranding, and Imitation of Foods, Beverages, Candies, Drugs, and Condiments in the District of Columbia and the Territories, and for Regulating Interstate Traffic Therein, and for Other Purposes. Washington, D.C.: U.S. Government Printing Office.

Costa, Dora. 2015. "Health and the Economy in the United States, from 1750 to the Present." Journal of Economic Literature, 53(3): 503-570.

Cutler, David, Angus Deaton, and Adriana Lleras-Muney. 2006. "The Determinants of Mortality." Journal of Economic Perspectives, 20(3): 97-120.

"Dangerous Milk Adulteration.” 1879. The Brooklyn Daily Eagle, July 7, p. 2.

Drescher, August. 1893. "Report of August Drescher, Chemist." Report of the Dairy Commissioner of the State of New Jersey for the Year 1892. Trenton, NJ: The John L. Murphy Publishing Company, Printers, pp. 49-60.

Ewbank, Douglas and Samuel Preston. 1990. "Personal Health Behavior and the Decline in Infant and Child Mortality: The United States, 1990-1930." In What We Know about Health Transition: The Cultural, Social, and Behavioral Determinants of Health (John Caldwell et al., eds.). Health Transition Center, Canberra: Australian National University.

Fogel, Robert. 1997. "New Findings on Secular Trends in Nutrition and Mortality: Some Implications for Population Theory." Handbook of Population and Family Economics, 1, Part A: 433-481.

Geisler, Joseph F. 1891. "Signification of Lactometer Tests." Journal of the American Chemical Society, 13 (2): 93-98.

Goodman-Bacon, Andrew. 2021. "Difference-in-Differences with Variation in Treatment Timing." Journal of Econometrics, 225(2): 254-277.

Haines, Michael. 2001. “The Urban Mortality Transition in the United States, 1800-1940.” Annales de Démographie Historique, 1: 33-64.

Hart, Leslie. 1952. "A History of the Adulteration of Food Before 1906." Food, Drug, Cosmetic Law Journal, 7(1): 5-22.

Higgs, Robert. 1979. "Cycles and Trends of Mortality in 18 large American Cities, 1871-1900." Explorations in Economic History, 16(4): 381-408.

“How Milk is Adulterated”. 1887. The Philadelphia Inquirer, November 12, p. 10. 
Kastle, Joseph H. 1908. "The Chemistry of Milk." In Milk and Its Relation to the Public Health, National Institutes of Health (Bulletin No. 41). Washington, D.C.: U.S. Government Printing Office.

Komisarow, Sarah. 2017. "Public Health Regulation and Mortality: Evidence from Early 20th Century Milk Laws.” Journal of Health Economics, 56(December): 126-144.

Lee, Kwang-Sun. 2007. "Infant Mortality Decline in the Late 19th and Early 20th Centuries: the Role of Market Milk." Perspectives in Biology and Medicine, 50(4): 585-602.

Lentzner, Harold. 1987. "Seasonal Patterns of Infant and Child Mortality in New York, Chicago and New Orleans.” Dissertation, University of Pennsylvania.

Litovitz, Toby L. Wendy Klein-Schwartz, Gary M. Oderda, Barbara F. Schmitz. 1988. "Clinical Manifestations of Toxicity in a Series of 784 Boric acid Ingestions." American Journal of Emergency Medicine, 6(3): 209-213.

“Long Live the Pump.” 1890. The Philadelphia Inquirer, June 25, p. 8.

Martin, Edward W. 1884. "Report on Milk and its Adulterations." Annual Report of the State Board of Health of New York. Albany, NY: Weed, Parsons, and Company, Legislative Printers.

McKeown, Thomas and R.G. Brown. 1955. "Medical Evidence Related to English Population Changes in the Eighteenth Century.” Population Studies, 9(2): 119-141.

McKeown, Thomas. 1976. The Modern Rise of Population. New York, NY: Academic Press.

Meckel, Richard. 1990. Saving the Babies: American Public Health Reform and the Prevention of Infant Mortality, 1850-1929. Baltimore, MD: Johns Hopkins University Press.

Morris, J. Cheston. 1885. "The Milk-Supply of Our Large Cities: The Extent of Adulteration and Its Consequences: Methods of Prevention” Public Health, Papers and Reports, 10: 246-252.

Newton, William K. 1877. "Our Milk Supply." Annual Report of the Department of Health of the State of New Jersey, 1877. Trenton, NJ: Nabb, Day \& Naab, Printers, pp. 209-235.

North, C.E. 1921. "Milk and Its Relation to Public Health." In A Half Century of Public Health (M.P. Ravenel, ed.). New York, NY: Public Health Association America.

Parker, Horatio N. 1917. City Milk Supply. New York, NY: McGraw-Hill Book Company, Inc.

“Pure and Impure Milk”. 1876. New York Daily Herald, February 21, p. 9.

Preston, Samuel and Michael Haines. 1991. Fatal Years: Child Mortality in Late Nineteenth-Century America. Princeton, NJ: Princeton University Press.

Rees, Jonathan. 2013. Refrigeration Nation. Baltimore, MD: Johns Hopkins University Press.

“Sale of Impure Milk" 1890. The Times (Philadelphia, PA), June 13, p. 3. 
See, Ang Swi, Abu Bakar Salleh, Fatimah Abu Bakar, Nor Azah Yusof, Ahmed Sahib Abdulamir, and Lee Yook Heng. 2010. "Risk and Health Effect of Boric Acid." American Journal of Applied Sciences, 7(5): 620-627.

Sun, Liyang and Sarah Abraham. 2021. "Estimating Dynamic Treatment Effects in Event Studies with Heterogeneous Treatment Effects.” Journal of Econometrics, 225(2): 175-199.

"The Adulteration of Milk." 1880. The New England Farmer (Boston, MA), February 21, p. 2.

“The Care of Infants Historical Data." 1912. Journal of the American Medical Association, 59(7): 542-543.

“The New Milk Law.” 1880. The New England Farmer (Boston, MA), September 25, p. 1.

Troesken, Werner. 2015. The Pox of Liberty: How the Constitution Left Americans Rich, Free, and Prone to Infection. Chicago, IL: University of Chicago Press.

Wolf, Jacqueline H. 2001. Don't Kill Your Baby: Public Health and the Decline of Breastfeeding in the 19th and 20th Centuries. Columbus, OH: Ohio State University Press.

Wolf, Jacqueline H. 2003. "Low Breastfeeding Rates and Public Health in the United States." American Journal of Public Health, 93(12): 2000-2010. 
Figure 1. Infant and Child Mortality Rates, 1880-1910

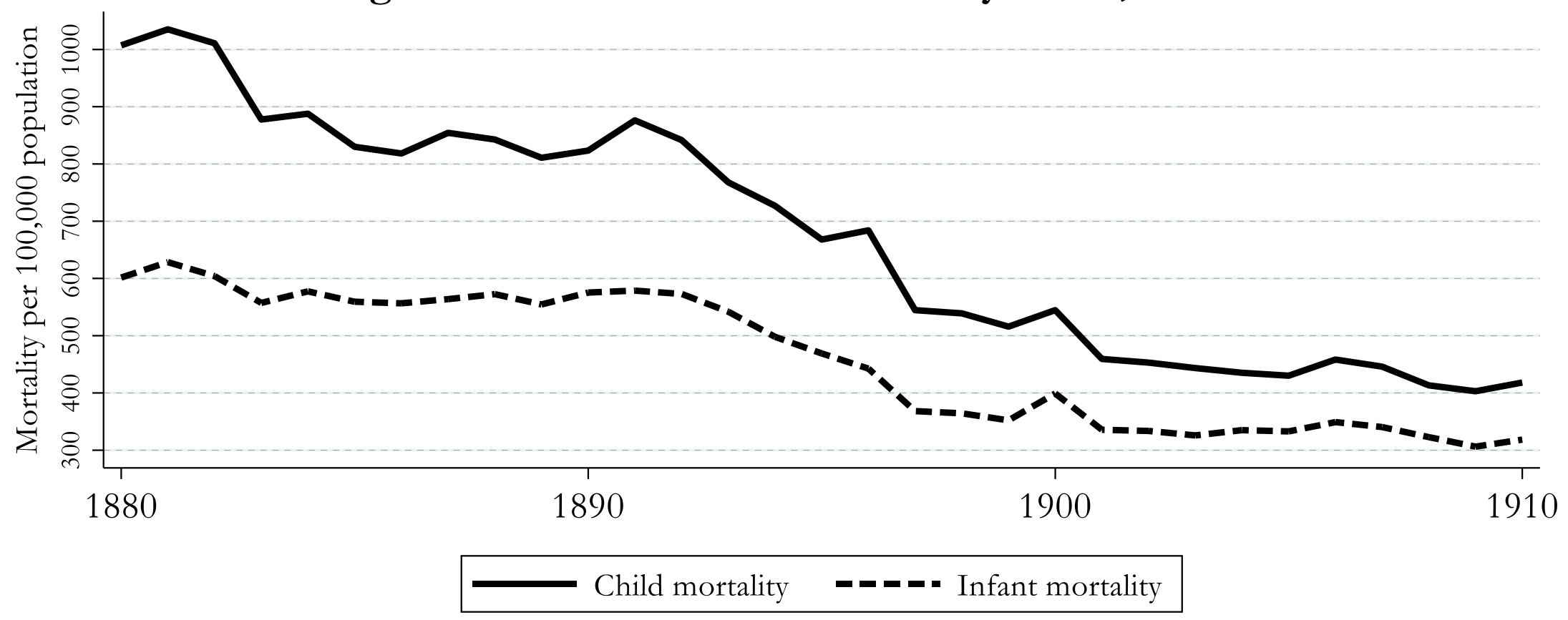

Notes: Based on annual data from municipal and state public health reports (1880-1899) and Mortality Statistics (1900-1910). 
Figure 2. Milk Inspections and Infant Mortality, 1880-1910
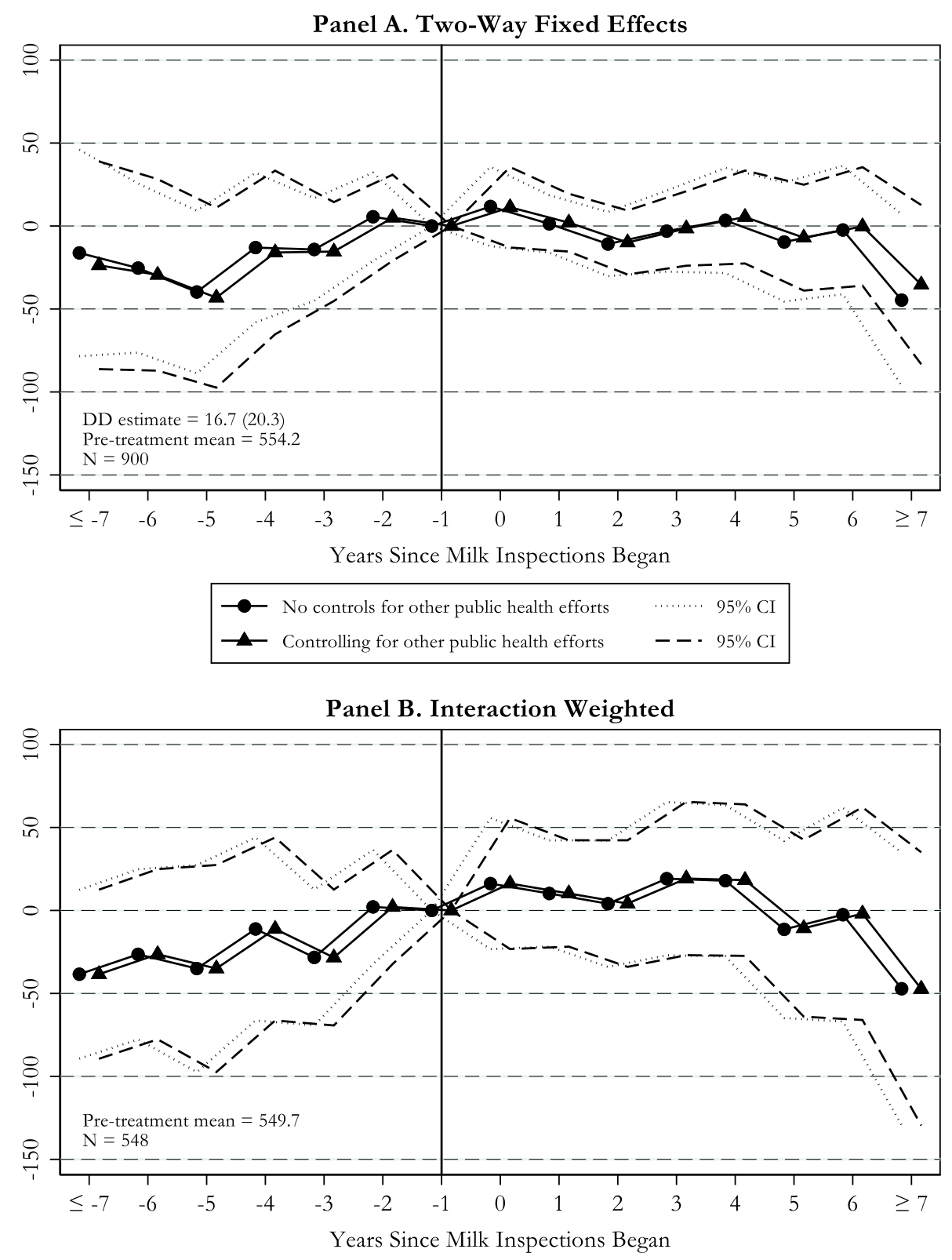

$$
\begin{aligned}
& - \text { No controls for other public health efforts } \\
& - \text { Controlling for other public health efforts } \\
& -\quad-\quad-95 \% \text { CI }
\end{aligned}
$$

Notes: Based on annual data from municipal and state public health reports (1880-1899) and Mortality Statistics (19001910). Two-way fixed effects (panel A) and interaction-weighted (panel B) estimates (and their $90 \%$ confidence intervals) are reported, where the omitted category is one year before treatment. The dependent variable is equal to the number of infant deaths per 100,000 population in city $c$ and year $t$. All models control for city and year fixed effects. Estimates are weighted by city population and standard errors are corrected for clustering at the city level. Reported DD estimate (panel A) comes from a regression that controls for other public health efforts in which the event-study indicators are replaced by the variable Inspection (equal to one if city $c$ was inspecting its milk supply in year $t$, and equal to zero otherwise). 
Figure 3. Milk Inspections and Child Mortality, 1880-1910

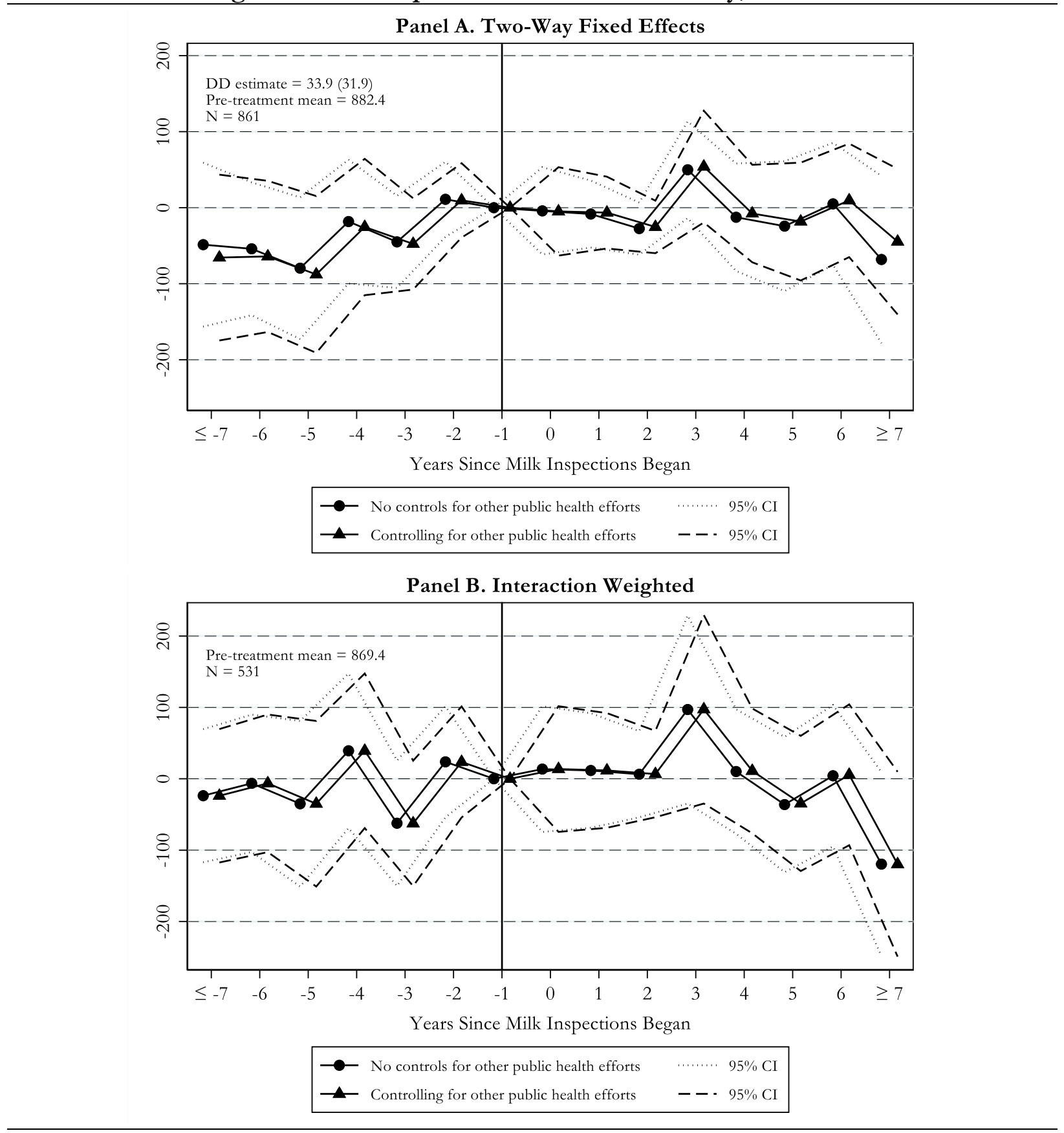

Notes: Based on annual data from municipal and state public health reports (1880-1899) and Mortality Statistics (19001910). Two-way fixed effects (panel A) and interaction-weighted (panel B) estimates (and their $90 \%$ confidence intervals) are reported, where the omitted category is one year before treatment. The dependent variable is equal to the number of deaths among children under the age of 5 per 100,000 population in city $c$ and year $t$. All models control for city and year fixed effects. Estimates are weighted by city population and standard errors are corrected for clustering at the city level. Reported DD estimate (panel A) comes from a regression that controls for other public health efforts in which the event-study indicators are replaced by the variable Inspection (equal to one if city $c$ was inspecting its milk supply in year $t$, and equal to zero otherwise). 


\section{Appendix}

For Online Publication 


\section{Appendix A}

Appendix Table 1. Municipal Milk Inspection Dates and Data Availability

\begin{tabular}{|c|c|c|c|}
\hline City and state & $\begin{array}{c}\text { Year milk } \\
\text { inspections began }\end{array}$ & $\begin{array}{c}\text { Years covered for } \\
\text { infant mortality counts }\end{array}$ & $\begin{array}{l}\text { Years covered for } \\
\text { child mortality counts }\end{array}$ \\
\hline Mobile, AL & 1905 & $1889-1910$ & $1889-1910$ \\
\hline San Francisco, CA & 1898 & 1881-1897, 1900-1910 & 1881-1897, 1900-1910 \\
\hline Bridgeport, CT & $\ldots$ & $1880-1910$ & $1880-1910$ \\
\hline Hartford, CT & 1883 & 1880-1881, 1883-1910 & 1880-1881, 1883-1910 \\
\hline New Haven, CT & $\ldots$ & $1880-1910$ & 1880-1910 \\
\hline Waterbury, CT & $\ldots$ & $1880-1910$ & 1880-1910 \\
\hline Washington, D.C. & 1893 & 1880-1910 & 1880-1910 \\
\hline Atlanta, GA & 1895 & $1893-1910$ & $1880-1910$ \\
\hline Chicago, IL & 1893 & $1880-1910$ & $1880-1910$ \\
\hline Indianapolis, IN & 1897 & 1884-1887, 1895-1896, 1899-1910 & 1884-1887, 1895-1896, 1899-1910 \\
\hline New Orleans, LA a & 1892 & $1881-1910$ & $\ldots$ \\
\hline Portland, ME & 1902 & $1887-1910$ & 1887-1910 \\
\hline Baltimore, MD & 1894 & 1880-1910 & 1880-1910 \\
\hline Grand Rapids, MI & 1897 & $1890,1892-1910$ & $1890,1892-1910$ \\
\hline St. Paul, MN & 1899 & $1885-1910$ & $1885-1910$ \\
\hline St. Louis, MO & 1887 & $1880-1896,1900-1910$ & $1880-1910$ \\
\hline Manchester, NH & 1884 & $1883-1910$ & $1883-1910$ \\
\hline Camden, NJ & 1883 & $1880-1910$ & 1880-1910 \\
\hline Elizabeth, NJ & 1883 & $1880-1910$ & $1880-1910$ \\
\hline Hoboken, NJ & 1883 & $1880-1910$ & $1880-1910$ \\
\hline Jersey City, NJ & 1883 & $1880-1910$ & $1880-1910$ \\
\hline Newark, NJ & 1883 & 1880-1910 & $1880-1910$ \\
\hline Paterson, NJ & 1883 & $1880-1910$ & $1880-1910$ \\
\hline Trenton, NJ & 1883 & $1880-1910$ & $1880-1910$ \\
\hline New York City, NY & 1883 & $1880-1897$ & $1880-1897$ \\
\hline Rochester, NY & 1891 & $1881-1910$ & $1881-1910$ \\
\hline Cleveland, $\mathrm{OH}$ & 1887 & $1880-1910$ & $1880-1910$ \\
\hline Dayton, $\mathrm{OH}$ & 1887 & $1880,1890-1891,1893-1896,1898-1910$ & $1880,1890-1891,1893-1896,1898-1910$ \\
\hline Toledo, $\mathrm{OH}$ & 1884 & $1881-1883,1885,1898-1910$ & $1881-1883,1885,1898-1910$ \\
\hline Philadelphia, PA & 1889 & $1880-1910$ & $1880-1910$ \\
\hline Memphis, TN & 1889 & $1880-1897,1900-1910$ & 1880-1897, 1900-1910 \\
\hline Richmond, VA & 1893 & $1887-1910$ & $1887-1910$ \\
\hline Milwaukee, WIa & 1891 & $1885-1890,1892-1910$ & $\ldots$ \\
\hline
\end{tabular}

a These cities are not included in the sample on child mortality because mortality counts are unavailable for the pre-treatment period. 


\section{Appendix Table 2. Descriptive Statistics}

\begin{tabular}{|c|c|c|}
\hline & $\begin{array}{c}\text { Mean } \\
\text { (SD) }\end{array}$ & Description \\
\hline Inspection & $\begin{array}{c}0.661 \\
(0.473)\end{array}$ & $=1$ if city sampled and inspected its milk supply, $=0$ otherwise \\
\hline Filtration & $\begin{array}{c}0.082 \\
(0.273)\end{array}$ & $=1$ if city had a water filtration plant, $=0$ otherwise \\
\hline Chlorination & $\begin{array}{c}0.005 \\
(0.063)\end{array}$ & $=1$ if city treated water supply with chlorine, $=0$ otherwise \\
\hline Clean Water Project & $\begin{array}{c}0.043 \\
(0.201)\end{array}$ & $=1$ if city had completed a clean water project, $=0$ otherwise \\
\hline $\mathrm{N}=900$ & & \\
\hline
\end{tabular}

Notes: Unweighted means with standard deviations in parentheses. 


\section{Appendix B}

\section{Sources for Milk- and Water-Related Pubic Health Interventions}

\section{Mobile, AL}

Kay, Edgar B. 1913. "Mobile Water Supply." In the Proceedings of the Thirty-Third Annual Convention of the American Water Works Association, 33: 587-596.

Parker, Horatio N. 1917. City Milk Supply. New York, NY: McGraw-Hill Book Company, Inc.

“Wants a Milk Inspector." 1905. Jones V alley Times, June 8, p. 2.

\section{San Francisco, CA}

"After the Milkmen." 1898. The San Francisco Examiner, May 29, p. 20.

“Disinfection of Water Supplies.” 1919. Municipal Journal and Public Works, 46 (24): 437-439, 444.

Eagle, Alexander. 1929. "The San Francisco Milk Supply and its Problems." Eighteenth Annual Report of the International Association of Dairy and Milk. Inspectors, pp. 218-226.

Schussler, Hermann. 1906. The Water Supply of San Francisco, California, Before, During and After the Earthquake of April 18th, 1906, and the Subsequent Conflagration. New York, NY: Martin B. Brown Press.

\section{Bridgeport, CT}

Barrows, Frank. C. 1933. "Steps in the Purification of the Bridgeport Water Supply." Journal of the New England Water Works Association, 47 (2): 219-222.

Woodward, Edwin G. 1936. "History of the Dairy and Milk Commission from its Creation in 1886. Fifty Years of Progress." Thirty-First Report of the Dairy and Food Commissioner. Hartford: State (State of Connecticut Public Document No. 32), pp. 13-22.

\section{Hartford, CT}

Board of Water Commissioners (Harford, CT). 1916 Sixty-Second Annual Report of the Board of Water Commissioners of the City of Hartford, Conn. for the year ending March 1, 1916. Hartford, CT: The Case, Lockwood, and Brainard Company.

"Inspection of Milk." 1882. Hartford Courant, November 28, p. 3.

“Sealer Robert's Annual Report-Marked Improvement in the Quality of Milk." 1883. Hartford Courant, May 15, p. 2. 
Woodward, Edwin G. 1936. "History of the Dairy and Milk Commission from its Creation in 1886. Fifty Years of Progress." Thirty-First Report of the Dairy and Food Commissioner. Hartford: State (State of Connecticut Public Document No. 32), pp. 13-22.

\section{New Haven, CT}

McCluskey, Dorothy S. and Claire C. Bennitt. 1997. "Partnerships Protect Watersheds: The Case of the New Haven Water Company." Land Lines, 9 (1): 1-3.

Woodward, Edwin G. 1936. "History of the Dairy and Milk Commission from its Creation in 1886. Fifty Years of Progress." Thirty-First Report of the Dairy and Food Commissioner. Hartford: State (State of Connecticut Public Document No. 32), pp. 13-22.

\section{Waterbury, CT}

Pape, William Jamieson. 1918. History of Waterbury and the Nangatuck Valley, Connecticut. New York: The S.J. Clarke Publishing Company.

Woodward, Edwin G. 1936. "History of the Dairy and Milk Commission from its Creation in 1886. Fifty Years of Progress." Thirty-First Report of the Dairy and Food Commissioner. Hartford: State (State of Connecticut Public Document No. 32), pp. 13-22.

\section{Washington, D.C.}

“A Milk Inspector Needed.” 1890. Evening Star (Washington DC), April 4, p. 6.

Cosby, Spencer. 1909. “The Water Supply of Washington” In (editor, John H. Walker) The

Purification of the Washington Water Supply (3rd edition), Washington, D.C.: Government Printing Office, Chapter 8, pp. 260-265.

“Milk Inspection” 1893. Evening Star (Washington DC), April 17, p. 7.

“Samples of Milk Tested” 1893. Evening Star (Washington DC), June 5, p. 6.

\section{Atlanta, GA}

Alvord, Henry Elijah and Raymond Allen Pearson. 1903. The Milk Supply of Two Hundred Cities and Towns. U.S. Department of Agriculture, Bureau of Animal Industry--Bulletin No. 46. Washington, D.C.: U.S. Government Printing Office.

Elmore, Bartow. 2010. "Hydrology and Residential Segregation in the Postwar South: An Environmental History of Atlanta, 1865-1895.” The Georgia Historical Quarterly, 94 (1): 30-61.

Garrett, Franklin M. 2011. Atlanta and Environs: A Chronicle of Its People and Events, 1880s-1930s. Athens: University of Georgia Press.

“Notice to Milk Dealers and Dairymen.” 1895. The Atlanta Constitution, July 16, p. 5. 
"Ruined His Milk." 1895. The Atlanta Constitution, August 29, p. 10.

"Sanitary Condition Vastly Improved by Recent City Ordinances." 1889. The Atlanta Constitution, February 23, p. 8.

"The Ordinance" 1888. The Atlanta Constitution, July 17, p. 8.

“Their Report Out.” 1896. The Atlanta Constitution (Atlanta, Georgia), May 15, p. 2.

"Want More Money." 1895. Heads of City Departments Tell Finance Committee What They Want." The Atlanta Constitution (Atlanta, Georgia), January 9, p. 5.

\section{Chicago, IL}

Baylis, John R. 1949. "Chicago South District Filtration Plant." Journal of the American Water Works Association, 41(7): 599-615.

Cain, Louis P. 1978. Sanitation Strategy for a Lakefront Metropolis: The Case of Chicago. DeKalb, IL: Northern Illinois University Press.

Gustaitis, Joseph. 2013. Chicago's Greatest Year, 1893: The White City and the Birth of a Modern Metropolis. Carbondale, IL: Southern Illinois University Press.

"Milk Must be Pure" 1892. The Chicago Tribune, October 17, p. 6

“Municipal Notes” 1893. Chicago Tribune, January 12, p. 9.

\section{Indianapolis, IN}

Calvert, C.K. 1934. “The Sanitary Works of Indianapolis.” American Journal of Public Health, 24(7): 739-742.

“Dairymen’s Milk Examined Dailey.” 1897. The Indianapolis News, November 8, p. 2.

“Disinfection of Water Supplies.” 1919. Municipal Journal and Public Works, 46(24): 437-439 and 444.

Jordan, H.E. 1909. "Preliminary Chemical Treatment as an Aid to Slow Sand Filtration; Indianapolis Water Company.” Engineering News, 66(6): 144-148.

Mabee, W.C. 1909. "Concrete in Waterworks Construction.” Fire and Water Engineering, 46: 242-244.

\section{New Orleans, LA}

"The Proposed Milk Inspection Ordinance." 1892. The Times Picayune, July 9, p. 3.

"Pure Milk." 1892. The Times-Democrat, September 24, p. 4. 
Porter, John L. 1909. "Operation and Maintenance Purification Stations." In the Semi-annual Report of the Sewerage and Water Board of the City of New Orleans, La, pp. 57-63.

Reeves, William D. 2003. Historic Lonisiana: An Illustrated History. San Antonio, TX: Historical Publishing Network.

\section{Portland, ME}

Parker, Horatio N. 1917. City Milk Supply. New York, NY: McGraw-Hill Book Company, Inc.

“The Portland Water Works System.” 1916. Fire and Water Engineering, 60(10): 169-171.

\section{Baltimore, MD}

"City Ordinances." 1894. Baltimore Sun, May 22, p. 9.

Hendrickson, Martha A. 2012. "The Montebello Water Filtration Plant I: Clean Water for City \& Suburb Alike." History Trails, 43(3-4): 1-20.

Jennings, C.A. 1918. "Some Results Secured by Chlorine Compounds in Water Purification and Sewage Treatment." Municipal Engineering, LV(1): 249-251

"Milk that was Below the Standard." 1894. Baltimore Sun, July 3, p. 8.

“To Test a Law.” 1894. Baltimore Sun, August 3, p. 8.

\section{Grand Rapids, MI}

Alvord, Henry Elijah and Raymond Allen Pearson. 1903. The Milk Supply of Two Hundred Cities and Towns. U.S. Department of Agriculture, Bureau of Animal Industry--Bulletin No. 46. Washington, D.C.: U.S. Government Printing Office.

Etten, William (editor). 1926. "Water Supply." In A Citizens' History of Grand Rapids, Michigan, Grand Rapids, MI: A.P. Johnson Company for the Campau Centennial Committee, pp. 122-127.

Michigan Dairy and Food Commission. 1897. Bulletin No. 28 (December). Lansing: Robert-Smith Printing Company.

\section{St. Paul, MN}

"Health Officer's Staff." 1899. Saint Paul Globe, May 2, p. 2.

“St. Paul, Minn., Water Report for 1913.” 1914. Fire and Water Engineering, 56(2): 20.

\section{St. Louis, MO}

"Milk and the Crematory." 1887. St. Louis Globe-Democrat, February 24, p. 8. 
Wall, Edward E. 1920. "Water Treatment at St. Louis Mo.” American Journal of Public Health, 10(5): 437-443.

\section{Manchester, $\mathbf{N H}$}

Ahlgren, Clarence L. 1959. "The Manchester Water Works." Water Works, Water and Sewage Works, 106(10): 427-430.

Littlefield, Chauncy B. 1884. "Manchester Milk Inspector, First Report of." Report of the State Librarian to the New Hampshire State Legislature. Concord, NH: Edward N. Pearson, Public Printer, p. 280.

State Board of Health (New Hampshire). 1884. "General Report." Report of the State Board of Health of the State of New Hampshire, Volume 3. Concord, NH: Parsons B. Cogswell, Public Printer, pp. 7-20.

\section{Camden, NJ}

Alvord, Henry Elijah and Raymond Allen Pearson. 1903. The Milk Supply of Two Hundred Cities and Towns. U.S. Department of Agriculture, Bureau of Animal Industry--Bulletin No. 46. Washington, D.C.: U.S. Government Printing Office.

Cooper, Howard Mickle. 1909. Historical Sketch of Camden, N. J. Camden, NJ: H. B. Ketler.

Newton, William K. 1884. "Sanitary Control of the Food Supply." Report of the State Board of Health of the State of New Hampshire for the Fiscal Year Ending April 30, 1884. Concord, NH: Parsons B. Cogswell, Public Printer, pp. 247-269.

"Inspecting the Milk." 1883. Courier-Post, July 20, p. 1.

“Milk Inspection Suit.” 1883. Courier-Post (Camden, New Jersey), Nov 9, p. 1.

\section{Elizabeth, NJ}

Alvord, Henry Elijah and Raymond Allen Pearson. 1903. The Milk Supply of Two Hundred Cities and Towns. U.S. Department of Agriculture, Bureau of Animal Industry--Bulletin No. 46. Washington, D.C.: U.S. Government Printing Office.

Newton, William K. 1884. "Sanitary Control of the Food Supply." Report of the State Board of Health of the State of New Hampshire for the Fiscal Year Ending April 30, 1884. Concord, NH: Parsons B. Cogswell, Public Printer, pp. 247-269.

“Water Purification in New Jersey." 1914. Municipal Journal and Public Works, 37 (4): 106-108.

\section{Hoboken, NJ}

Alvord, Henry Elijah and Raymond Allen Pearson. 1903. The Milk Supply of Two Hundred Cities and Towns. U.S. Department of Agriculture, Bureau of Animal Industry--Bulletin No. 46. Washington, D.C.: U.S. Government Printing Office. 
"Filtration Plant at New Milford." 1906. Fire and Water Engineering, July 10, pp. 7-10.

Newton, William K. 1884. "Sanitary Control of the Food Supply." Report of the State Board of

Health of the State of New Hampshire for the Fiscal Year Ending April 30, 1884. Concord, NH:

Parsons B. Cogswell, Public Printer, pp. 247-269.

“The Purification of Water by Aeration.” 1885. Engineering News, 13: 134.

\section{Jersey City, NJ}

Alvord, Henry Elijah and Raymond Allen Pearson. 1903. The Milk Supply of Two Hundred Cities and Towns. U.S. Department of Agriculture, Bureau of Animal Industry--Bulletin No. 46. Washington, D.C.: U.S. Government Printing Office.

Jennings, C.A. 1918. "Some Results Secured by Chlorine Compounds in Water Purification and Sewage Treatment." Municipal Engineering, LV(1): 249-251.

“Jersey Has a New Reservoir”. 1904. The Sun (New York, New York), January 24, p. 15.

McGuire, Michael J. 2013. The Chlorine Revolution: Water Disinfection and the Fight to Save Lives. Denver, CO: American Water Works Association.

Newton, William K. 1884. "Sanitary Control of the Food Supply." Report of the State Board of Health of the State of New Hampshire for the Fiscal Year Ending April 30, 1884. Concord, NH: Parsons B. Cogswell, Public Printer, pp. 247-269.

\section{Newark, NJ}

Alvord, Henry Elijah and Raymond Allen Pearson. 1903. The Milk Supply of Two Hundred Cities and Towns. U.S. Department of Agriculture, Bureau of Animal Industry--Bulletin No. 46. Washington, D.C.: U.S. Government Printing Office.

“Chlorine Disinfection in Water-Works Plants.” 1917. Water and Gas Review, 27(10):17-22.

“Disinfection of Water Supplies.” 1919. Municipal Journal and Public Works, 46 (24): 437-439 and 444.

Newton, William K. 1884. "Sanitary Control of the Food Supply." Report of the State Board of Health of the State of New Hampshire for the Fiscal Year Ending April 30, 1884. Concord, NH: Parsons B. Cogswell, Public Printer, pp. 247-269.

“Water Purification in New Jersey.” 1914. Municipal Journal and Public Works, 37(4): 106-108.

\section{Patterson, NJ}

Alvord, Henry Elijah and Raymond Allen Pearson. 1903. The Milk Supply of Two Hundred Cities and Towns. U.S. Department of Agriculture, Bureau of Animal Industry--Bulletin No. 46. Washington, D.C.: U.S. Government Printing Office. 
Fuller, George W. 1901. "The Water Purification Works of the East Jersey Water Company at Little Falls, New Jersey." The Engineering Record, 43(19): 442-444.

Newton, William K. 1884. "Sanitary Control of the Food Supply." Report of the State Board of Health of the State of New Hampshire for the Fiscal Year Ending April 30, 1884. Concord, NH: Parsons B. Cogswell, Public Printer, pp. 247-269.

\section{Trenton, NJ}

Alvord, Henry Elijah and Raymond Allen Pearson. 1903. The Milk Supply of Two Hundred Cities and Towns. U.S. Department of Agriculture, Bureau of Animal Industry--Bulletin No. 46. Washington, D.C.: U.S. Government Printing Office.

Newton, William K. 1884. "Sanitary Control of the Food Supply." Report of the State Board of Health of the State of New Hampshire for the Fiscal Year Ending April 30, 1884. Concord, NH: Parsons B. Cogswell, Public Printer, pp. 247-269.

“Water Purification in New Jersey." 1914. Municipal Journal and Public Works, 37 (4): 106-108.

“Water Purification at Trenton.” 1914. Municipal Journal and Public Works, 37 (17) 589-591.

\section{New York City, NY}

"A Milk Company in Trouble" 1883. New-York Tribune, July 29, p. 12.

Coffin, T.D.L. 1913. “Chlorinating Plants, Croton Water Supply.” Engineering News, 69(9): 419-422.

"Frauds in the Sale of Foods and Drugs." 1883. New-York Tribune, February 13, p. 4.

New York City (NY), Public Works Dept. 1890. Report of the Department of Public Works of the City of New York for the Quarter Ending September 30, 1890. New York, NY: Martin B. Brown.

"Skimmed Milk Poured in the Street." 1883. New-York Tribune, March 16, p. 5.

“The Filling of the New Croton Reservoir.” 1908. The Engineering Review, 18(1): 53.

\section{Rochester, NY}

Horton, Theodore. 1922. "The Influence of Engineering Work of Public Health Departments in the Reduction of Mortality." Transactions of the Second Annual Antimalaria Conference of Sanitary Engineers (Public Health Bulletin No. 120). Washington, D.C.: U.S. Government Printing Office, pp. 5-15.

“Milkmen Arrested." 1891. Democrat and Chronicle, September 16, p. 8.

McKelvey, Blake. 1972. “Water for Rochester.” Rochester History, 34(3): 1-24. 
Rochester (NY), Department of Environmental Services, Bureau of Water. 2013. A Pocket History of the Rochester Water Works, Rochester New York.

“Two New Ordinances.” 1891. Democrat and Chronicle, May 15, p. 10.

\section{Cleveland, $\mathbf{O H}$}

Beckwith, D.H. 1887. "Sophistication of Food and Drinks." Proceedings the Twenty-Fourth Annual Session of the Homeopathic Medical Society of the State of Obio Held at Delaware, May 8 and 9, 1888, pp. 7885.

Orth, Samuel Peter. 1910. A History of Cleveland, Obio, Volume 1. Chicago-Cleveland: S.J. Clarke Publishing Company.

Perkins, Roger G. 1921. "Typhoid Fever in Cleveland Ohio for the Years 1918, 1919, and 1920.” Public Health Reports, 36(20): 1095-1132.

Stradling, David and Richard Stradling. 2015. Where the River Burned: Carl Stokes and the Struggle to Save Cleveland. Ithaca, NY: Cornell University Press.

\section{Dayton, $\mathbf{O H}$}

"The Milk Tester." 1887. The Dayton Herald, August 15, p. 3.

"Poor Milk." 1882. The Dayton Herald, July 12, p. 4.

Drury, Augustus Waldo. 1909. History of the City of Dayton and Montgomery County, Ohio. Chicago IL: S.J. Clarke Publishing Company.

\section{Toledo $\mathbf{O H}$}

Fox, Carroll. 1915. "Public Health Administration in Toledo." Public Health Reports, 30 (26): 18731932.

Furman, R. W. 1937. "Experiments with Sub-Surface Filters at Toledo, Ohio." Journal of the American Water Works Association, 29 (2): 194-200.

Reilly ,James. 1888. "Report of the Meat and Milk Inspector." Annual Statement of the Finances of Toledo: the Mayor's Annual Message and Reports of the Various Municipal Departments for the Year Ending December 31, 1887. Toledo (Ohio): B.F. Wade Company, pp. 419-420.

Toledo (OH), Auditor's Office. 1885. City Auditor for the Year Ending December 31, 1884, Annual Report, Vol. 14. Toledo, OH: The B.F. Wade Company, p. 97.

\section{Philadelphia, PA}

"Can be Read at a Glance." 1889. The Philadelphia Inquirer, January 16, p. 3. 
"Death Lurking in Milk". 1888. The Philadelphia Inquirer, December 5, p. 2.

“Long Live the Pump.” 1890. The Philadelphia Inquirer, June 25, p. 8.

"Sale of Impure Milk." 1890. The Times, June 13, p. 3.

“The City’s Milk Supply.” 1889. The Times, August 18, p. 2.

Philadelphia (PA), Bureau of Water. 1909. Description of the Filtration Works and Pumping Stations: Also Brief History of the Water Supply. Philadelphia, PA: Bureau of Water.

West, Francis D. 1909. "Sanitary Control of Filter Plants." Proceedings of the Engineers' Club of Philadelphia, 26(2): 135-144.

West, Francis D. 1914. "Disinfecting 200,000,000 Million Gallons of Water a Day-Experience with Chloride of Lime and Liquid Chlorine at the Torresdale Filtration Plant." Journal of the American Water Works Association, 1(3): 403-446.

\section{Memphis, TN}

Hardin, Eugene. 1932. "Design and Operation Data on Large Rapid Sand Filtration Plants in the United States and Canada." Journal of the American Water Works Association, 24(8): 1190-1207.

JAMA (editorial board). 1921. "Typhoid in the Large Cities of the United States in 1920." Journal of the American Medical Association, 76(13): 860-863.

JAMA (editorial board). 1922. "Typhoid in the Large Cities of the United States in 1921." Journal of the American Medical Association, 78(12): 890-893.

Montrie, Chad. 2005. "From Dairy Farms to Housing Tracks Environment and Race in the Making of a Memphis Suburb." Journal of Urban History, 31 (2): 219-240.

Preble, Paul. 1921. "Review of Public Health Administration in Memphis, Tennessee." Public Health Bulletin No. 113. Treasury Department, United States Public Health Service.

"Police are at Work Enforcing Sanitary Laws." 1898. The Commercial Appeal, July 19, p. 5.

“Under the Milk Ordinance.” The Commercial Appeal, December 9, p. 5.

"Will Get a Chemist. Dairymen will have Milk Inspection of their Own." 1898. The Commercial Appeal, December 4, p. 13.

\section{Richmond, VA}

"Against Impure Milk." 1893. The Daily Times, March 24, p. 5. 
Richmond (VA), Office of the City Water Works. 1910. Annual Report of the Superintendent of the City Water-Works to the Mayor of the City, for the Fiscal Year Ending December 31, 1909. Richmond, VA: Clyde W. Saunders.

\section{Milwaukee, WI}

Alvord, Henry Elijah and Raymond Allen Pearson. 1903. The Milk Supply of Two Hundred Cities and

Towns. U.S. Department of Agriculture, Bureau of Animal Industry--Bulletin No. 46. Washington, D.C.: U.S. Government Printing Office.

Foss-Mollan, Kate. 2001. Hard Water: Politics and Water Supply in Milwankee, 1870-1995. West Lafayaette, IN: Purdue University Press.

Jennings, C. A. 1918. "Some Results Secured by Chlorine Compounds in Water Purification and Sewage Treatment.” Municipal Engineering, LV(1): 249-251.

Leavitt, Judith W. 1996. The Healthiest City: Milwankee and the Politics of Health Reform. Madison Wisconsin: University of Wisconsin Press. 